\title{
Protocol
}

\section{Gel Purification of RNA}

\author{
Timothy W. Nilsen
}

For many applications, including size selection of RNAs and purification of in vitro transcription products, it is necessary to purify RNAs on a denaturing gel. This procedure describes how to purify transcripts that have been synthesized in vitro. It is useful for labeled or unlabeled RNAs when sufficient mass is present. It can also be used to isolate small RNAs. In general, RNA purification by denaturing gel electrophoresis is practical only when the size of the desired RNA is 600 nucleotides or less.

\section{MATERIALS}

It is essential that you consult the appropriate Material Safety Data Sheets and your institution's Environmental Health and Safety Office for proper handling of equipment and hazardous materials used in this protocol.

RECIPES: Please see the end of this article for recipes indicated by $<R>$. Additional recipes can be found online at http://cshprotocols.cshlp.org/site/recipes.

Reagents

Chloroform

Denaturing polyacrylamide gel (see Step 4)

EDTA (2 mm, pH 8.0)

Ethanol (100\%)

Formamide gel-loading buffer $<\mathrm{R}>$

Gel elution buffer $<\mathrm{R}>$

Phenol:chloroform (1:1)

Sample of RNA

This procedure describes how to purify transcripts that have been synthesized using the protocol In Vitro Transcription of Labeled RNA: Synthesis, Capping, and Substitution (Nilsen and Rio 2012). It can also be used for other cellular RNAs or small RNAs (e.g., those described in Preparation of Small RNA Libraries for HighThroughput Sequencing [Malone et al. 2012]).

TBE electrophoresis buffer $(10 \times)<\mathrm{R}>$

Equipment

Dry ice

Electrophoresis apparatus for denaturing polyacrylamide gel and power supply

Adapted from RNA: A Laboratory Manual, by Donald C. Rio, Manuel Ares Jr, Gregory J. Hannon, and Timothy W. Nilsen. CSHL Press, Cold Spring Harbor, NY, USA, 2011.

(c) 2013 Cold Spring Harbor Laboratory Press

Cite this article as Cold Spring Harb Protoc; 2013; doi:10.1101/pdb.prot072942 
Fluorescent markers (luminescent paint) also available commercially from art supply stores Hand-held ultraviolet (UV) light (254 nm)

Ice

Microcentrifuge

Microcentrifuge tubes

Plastic wrap

Scalpel or single-edge razor blade

Temperature block $\left(95^{\circ} \mathrm{C}\right)$

$\mathrm{X}$-ray film and developer

$\mathrm{X}$-ray intensifying screen

1. After phenol:chloroform:isoamyl alcohol (PCA) extraction and precipitation of the RNA with ethanol, resuspend RNA from a $50-\mu \mathrm{L}$ transcription or $5^{\prime}$ - or $3^{\prime}$-end-labeling reaction in $2.5 \mu \mathrm{L}$ of $2 \mathrm{~mm}$ EDTA (pH 8), and add $5 \mu \mathrm{L}$ of formamide gel-loading buffer.

2. Prepare a denaturing polyacrylamide gel as described in Polyacrylamide Gel Electrophoresis of RNA (Rio et al. 2010). Set up the gel in the gel box, add TBE electrophoresis buffer (diluted to $1 \times$ ) to the upper and lower reservoirs, and prerun the gel for $15-45 \mathrm{~min}$ at a maximum of $1500 \mathrm{~V} / 45 \mathrm{~mA}$.

If the RNA transcript is greater than 100 nucleotides, do shorter preruns (15-20 min).

3. Heat the sample from Step 1 for $1 \mathrm{~min}$ at $95^{\circ} \mathrm{C}$ and then place it on ice.

4. Load the sample. Use one lane for the RNA from one 50- $\mu \mathrm{L}$ transcription reaction (see In Vitro Transcription of Labeled RNA: Synthesis, Capping, and Substitution [Nilsen and Rio 2012]). If total cellular RNA is labeled, load it at 5-10 $\mu \mathrm{g}$ per lane. These amounts will not overload the lanes. (Refer to Polyacrylamide Gel Electrophoresis of RNA [Rio et al. 2010] to decide which gel to run.) Run the gel at a maximum of $1500 \mathrm{~V} / 45 \mathrm{~mA}$ until the bromophenol blue dye is about halfway down the gel.

If the sample is run too far, unincorporated radiolabel will be present in the lower buffer chamber, increasing the chances of unwanted contamination. This will not affect the RNA preparation, but it makes the cleanup process more time-consuming.

If the RNA is not radiolabeled, proceed to Step 5; if the RNA is radiolabeled, proceed to Step 6.

5. If the RNA is not radiolabeled, visualize the band by UV shadowing.

i. Remove one glass plate and cover the gel with plastic wrap.

ii. Cut a wide area of the gel expected to contain the band of RNA and transfer it (plastic wrap side down) to a clean X-ray intensifying screen.

iii. Shine the UV light on the gel piece.

The exact location of the RNA band will appear purple in the gel under UV light.

iv. Excise the band with a razor blade and then proceed to Step 7.

6. If the RNA is radiolabeled, visualize the band as follows:

i. Remove one glass plate and cover the gel with plastic wrap. Place fluorescent ink markers on the corners of the gel and expose the gel to X-ray film.

High-specific-activity transcripts should require 10-30 sec; trace-labeled transcripts may take 5-10 min. 
T. W. Nilsen

\section{RECIPES}

Formamide Gel-Loading Buffer

Quantity Final

Reagent

(for $10 \mathrm{~mL}$ ) concentration

Deionized formamide

$9.5 \mathrm{~mL}$

$95 \%$

Bromophenol blue

$2.5 \mathrm{mg}$

$0.025 \%(\mathrm{w} / \mathrm{v})$

Xylene cyanol FF

$2.5 \mathrm{mg}$

$0.025 \%(\mathrm{w} / \mathrm{v})$

EDTA (0.5 M, pH 8.0)

$100 \mu \mathrm{L}$

$5 \mathrm{~mm}$

$\mathrm{H}_{2} \mathrm{O}$

$400 \mu \mathrm{L}$

Store in aliquots at $-20^{\circ} \mathrm{C}$.

\section{Gel Elution Buffer}

\begin{tabular}{lcc} 
Reagent & $\begin{array}{c}\text { Quantity } \\
\text { (for } 500 \mathrm{~mL})\end{array}$ & $\begin{array}{c}\text { Final } \\
\text { concentration }\end{array}$ \\
\hline Tris- $\mathrm{HCl}(1 \mathrm{M}, \mathrm{pH} 7.5)$ & $10 \mathrm{~mL}$ & $20 \mathrm{~mm}$ \\
Sodium acetate $(2.5 \mathrm{M}$, prepared & $50 \mathrm{~mL}$ & $0.25 \mathrm{M}$ \\
without pH adjustment) & & $1 \mathrm{~mm}$ \\
EDTA $(0.5 \mathrm{M}, \mathrm{pH} 8.0)$ & $12.5 \mathrm{~mL}$ & $0.25 \%$ \\
SDS $(10 \%, \mathrm{w} / \mathrm{v})$ & $426.5 \mathrm{~mL}$ & \\
$\mathrm{H}_{2} \mathrm{O}$ &
\end{tabular}

If the SDS precipitates, warm to $37^{\circ} \mathrm{C}$ until the precipitate disappears. Store indefinitely at room temperature. 
TBE Electrophoresis Buffer (10X)

\begin{tabular}{lcc} 
Reagent & Quantity (for 1 L) & Final concentration \\
\hline Tris base & $121.1 \mathrm{~g}$ & $1 \mathrm{M}$ \\
Boric acid & $61.8 \mathrm{~g}$ & $1 \mathrm{M}$ \\
EDTA (disodium salt) & $7.4 \mathrm{~g}$ & $0.02 \mathrm{M}$
\end{tabular}

Prepare with RNase-free $\mathrm{H}_{2} \mathrm{O}$. Dilute $100 \mathrm{~mL}$ to $1 \mathrm{~L}$ to make gel running buffer. Store for up to 6 mo at room temperature.

\section{REFERENCES}

Malone C, Brennecke J, Czech B, Aravin A, Hannon GJ. 2012. Preparation of small RNA libraries for high-throughput sequencing. Cold Spring Harb Protoc doi: 10.1101/pdb.prot071431.

Nilsen TW, Rio DC. 2012. In vitro transcription of labeled RNA: Synthesis, capping, and substitution. Cold Spring Harb Protoc doi: 10.1101/pdb. prot072066.
Rio DC, Ares M Jr, Hannon GJ, Nilsen TW. 2010. Polyacrylamide gel electrophoresis of RNA. Cold Spring Harb Protoc doi: 10.1101/pdb. prot5444. 


\section{Gel Purification of RNA}

Timothy W. Nilsen

Cold Spring Harb Protoc; doi: 10.1101/pdb.prot072942

\begin{tabular}{rc}
\hline $\begin{array}{r}\text { Email Alerting } \\
\text { Service }\end{array}$ & Receive free email alerts when new articles cite this article - click here. \\
\hline $\begin{array}{c}\text { Subject } \\
\text { Categories }\end{array}$ & Browse articles on similar topics from Cold Spring Harbor Protocols. \\
& Electrophoresis of Nucleic Acids (62 articles) \\
& Electrophoresis of RNA (23 articles) \\
& Molecular Biology, general (1293 articles) \\
& RNA (317 articles) \\
& RNA Purification (76 articles) \\
\hline
\end{tabular}

